教育デアル。

数育事業丹二ッニ分ツ。一ッハ小學校 中等學校二於ヶル性敉育. 他八出版物 = シ テ. P. H. S. 八 100 種以上. 其, Copies 3 千萬尹出シタ.ソノ他カード ホスター。スライド」，配付キナス。州 八衙生課卜協力シテ满演會习催シ。本病

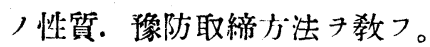

學校二於ケル訬教育尹ナスタメ

H. S. 八講演, 梗概卜插畫尹入レタ $\mathrm{Bu}$ lletines 7 用意ス。コノ册子中二八人間 八發生二關ス儿說朋圖. 疾病, 穌防方法. 個人衞生ノ規则等が書イテアル。

現今デハ性教育ガ非常二進步シ．其結 果ハ各州二於ケル花柳病取締二關ス儿規 則キ一定スル事ガ出來タ。

多クノ州二於テ花柳病治療二關スル山 阨的治療綝，販賣キ禁ジタ。統一七ル法 律デハ賣笑婦ノ取締リタ定メ。花柳病タ 傳染七シメタ者丹罰スル事トシタ。

淮外カラ八報告モ主要. 例へバ丁抹八 116 年間二政府八無代デ治療シタ. 徽毒 八過去 25 年間 $=33 \%$ 減ジ淋病ハソレ 程減ジナイ。

本部，豫算八 75,000弗二シテ. 政府 八 1925 年以來協力事業二對 シ 補助入ル 事トシタ.ソノ結果各州ノ花柳病八著シ ク減:ジ。

本病二對シテ長期ノ戰爭要ス。

\section{Micro-Manipulative Technique}

\section{第七細菌血清學部 中 島 壽}

Micro-Manipulator $=$ 八式 C. V. Taylor 式. T. Péterfi 式 R. Chambers 式等アリ：各其構造 モ其目的トスル處八 Experimental Embryology, Protozology, Cell Physi- ology, Bacteriology 等, 研究二於テ細 胞其他，組織成分，物理的性狀，研究. 種々， Menstrua 內二於ヶル細胞. 緗胞 膜等，Fragility，檢查諸種溶液，細胞 內注射實驗 (Protoplasma $\mathrm{PH}$ ）测定. Protoplasma，酸化還元力/检查等) 單 細菌、單細胞等/分解及ビ其培養試驗立立 ビ 二動物實驗. 細胞內成分, 分離緗胞， Electrometrie 等, 諸實驗二應用シ得ル モ.ナリ余八五記三式中 R. Chambers 氏考案, Micro-Manipulator , 實際 二使用ノ經驗アルナ以テ以下之二就キ略 述セントス。

構造 (第 1 ，第 2 圖參照)一硬キ金屬板 上ニアル Pillar $(\mathrm{F})$ 内 $=$ Manipulator 丹固定ス次二㙷微鏡 7 同一板上: 二固定 ス. 金屬板上ノ側面二アル穴二 Pillar 尹固定スレバ影微鏡ノ侧面ヨリ實驗操作 于行フ事子得. 目的二依り 2 個又心 3 個 , Micro-Manipulator $尹$ 同時二金屬板 上二固定スル事可能ナリ。顯微鏡/種類 二依り Manipulator /高サハ Pillar(F) ニアル㹉ニヨリ適宜二加減スル事キ得.

$\mathrm{R}$ 人捱二テ Micro-Needle 又八 Micropipette $\Rightarrow$ Moist Chamber (第 2 圖 T及 ビ第 8 圖) 内二固定ス. $\mathrm{Q}$ /捩二テ $\mathrm{Nee}$ dle 又八 Pipette/高サ 加減入. S , 据二テ其先端尹略 3 視野/ 中心二固定ス $\mathrm{G}$ 及ビ $\mathrm{H}$ 据卜 3 枚, 金屬板卜 關係及ビ I 据卜 2 枚, 金屬板卜，關係八第 7 圖 $\mathrm{b}$ 及ビ a /如シ。針/先端ハF及ビ $\mathrm{E}$ 點

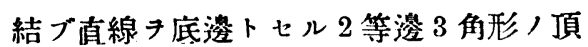

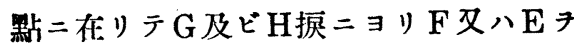
中心ト七ル圓周上 $尹$ Po 及ピ $\mathrm{Mn}$ ，方 向二 Horizontal ，弦運動キナス. I 㨝 ニョリ針ノ先端ハL點 中心ト七ル圓周 上习 $\mathrm{yz}$ ，方向二 Vertical ，弦運動尹 
ナス. 即千 G. H. I. / 3 個掘二低り Needle 又心Pipette /先端ガ顯微鏡視 野内二於テ Horizontal 及ビ Vertical =3 Dimensions ノ弦運動キナス. 詳細 人訅明八 R. Chambers, New Apparatus and Methods for the Dissection and Injection of Living Cells, The Anatomical Record, Vol. 24, No. 1. 1922, 及ビ E. Leitz 會社登行, Pamphlet No. 1086 二位り.鏡㝨上:固定ス ル Moist-Chamber (第 4 圖)。，面兩 侧二ハ蒸溜水ニテ濕シタル滤紙き插シ込 之實驗中可檢物，乾燥キ防グ. 可檢物ハ Deckglas, 下面二戴セ Moist-Chamber 上 $=$ Vaseline 二テ對銷入 Moist-Chamber 八顯微鏡, Condensor / 焦默距雄 ニョリ. 其高サキ加減スル事必要ナリ. 油浸 Lens，使用可能ナリ.亦 Ettisch, Péterfi 氏考案, Zeiss, Special Substage Condensor 尹用フル時八暗視野, 焦用可能ナリ。

Micro-Needle，製法（第 12 圖及第 13 圖) -Bunsen 燈上二テ外徑 $0.3-0.5$

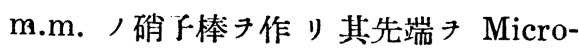
Burner 上ニテ b/如ク弓延バシ. 其先 端于更二 c. d. e. 八如ク曲グ.先端ノ形 八目的二依り異ニスルモ Amoeba 等， Dissection ニハ $\mathrm{c}$ 及ビ $\mathrm{d}$ 型, 2 本用つ ルガ便利ナリ、家鬼血球等, 如 $\neq$ delicate ノモノ、Puncture 二八 $\mathrm{i}$ 型 Tearing 等/目的ニ八 $\mathrm{j}$ 及ビ $\mathrm{i}$ 型, 2 本ガ 適當 /如シ。是等ノ針八其先端 Spring ノ活キスルキ以テ delicate, Manipulation二適ス。

Micro-pipettes，製法 (第 10 圖)一軟 質硝子管 $コ$ 外徑 $0.3-0.5$ m.m. ，細 毛細管 作り。其先端 7 Micrc-Burner
上ニテ引延バシ約 110 度二曲グ. 是等 鏡检スル時其先端種々ナルキ認ムルモ Micro-Injection /目的ニ八n及ビ $\mathrm{p}$ ， 型ガ適當ナリ. 其理由八其先耑尹 Deckglas，下面二觸レテ破ル時 n. $\mathrm{p}$ ，型， Pipette ガ比較的 Square，ロガ得ラル ル故ナリ，亦實驗中先端口ガ封ゼラル、 事㕌了アルキ以テ. 更二 Deckglas 二觸 レテロ 比較的 Square 二破ル事可能ナ ル故ナリ。該 Pipette 八“De Khotinsky”, Cement ニテ Adapter =固定 ス. 注射二際シテ八注射器及八護謨帽二 $\exists$ リ壓力 $\Rightarrow$ 送ル (第 2 圖 V) 第 13 圖 $\mathrm{d}$ 型 人針卜第 10 圖 $\mathrm{n}$ 及ハ $\mathrm{p}$ 型, Pipette キ同時二使用スルガ便利ナル事アリ。 Micro-Dissection, Micro-Injection 子應用七几呼究二八 ( 1 ) Protoplasma， Function 及 Structure，維持二大切 ナ Electrolyte，役目き检スル目的デ Amoeba Proteus 二種々， $\mathrm{pH} ， \mathrm{Na}$. K. Ca. Mg. 等, Chloride 尹注入七 ル R. Chambers 氏等, 實驗 (1) MicroDissection キ應朋シテナセルW. Seifriz 氏, Protoplasma，物理的性狀，詳細 ナル研究 (1) Narcotica, Zucker, Glycerin, Pikrin 酸等, Amoeba 體內注入 實驗 (1) Amoeba 蛙, 組織, Protoplasma $\mathrm{pH}$ 測定，實驗 (1) 生理的病的二於 ケル組織細胞ノ $\mathrm{pH}$ 測定, 實驗等アリ。 Protoplasma pH /測定二八 Vles, $\mathrm{Ne}$ edham, Pantin 氏等考案, Micro-Colorimeter，1例子顯微鏡, 反射鏡き介シ テ視野队二映スカ及八 Chart卜比較決 定ノ方法用ヒラル、ガ如シ. 溶液, 細胞 内注射分量八 Micro-Pipette 内二水銀 又八油 (Nuyol) キ入レ. 其，Meniscus ノ動キデ分量, 加減可能ナリ。 
Micro-Isolation (第 9 圖)一之二用ノル Micro-Pipette ニ八. 临通毛細管 Pipette ノ先端 Micro-Burner 上ニテ兩側二 引キ切儿時二八比較的 Square 八ロ 持 ツipette $尹$ 得ラル其先端部 P Pipette ノロト管ノ軸卜ガ略、本行スル樣二曲ゲ ル時ハ Pipette，口全體が Deckglas 二接三得テ可檢物, 吸收. 排泄二便ナリ. 第 9 圆二於ヶル II 及ビ田型ノ 2 本ヨ用> ルガ便ナリ：Micro-Pipette，口徑八可 檢物ノ大サ二依りテ加減製造ス。暗視野 二於テ Spirochaeta 等, 分歡:ニ八比較 的口徑大ナル Micro-Pipette キ用ヒザレ バ絡マリテ損稘スル盧レアリ。潒メ減菌 七ル硝子管ヨリ實驗, 直前二 Pipette キ作ルガョシ. 乾熱隇菌シ又八永ク保存 七ル Pipette 八先端二塵埃，附着著シク 分静二不適當ナリ。

隇菌 Deckglas /下面二可檢物ノ一滴 ヨ载七テ Moist-Chamber 上二固定 一側，Micr(o-pipette 尹以テ可检物） 少量き吸七取リ。第12圖人如ク MicroPrups 尹作ル。唯 1 個ノ菌又八細胞き含 ム小滴习認メタル時八像メ培養液, 少量 ヨ吸七取レル他側， Micro-Pipette 上テ之チ吸收ス. 該 Pippette 尹 Manipulator ヨリ取リハズシ培養液ノ入レル 試驗管壁二テ先端タ拆りテ投ズ. 或ハ之 子動物注射其他，目的二使用入. Pipette ，先椯き視野，略了中央二持于來タシ又 八目的物吸七取レル Pipette 7 MoistChamber $\exists$ 引キ出不等二八 W. H. Wright 及ビ Miss MeCoy 兩氏考案， 附屬器キ用フル事便利ナリ(第 2 圖W).

Micro-Prup，菌又八細狍數ノ計算 $=\exists$ り適宜，目的數，分離モ可能ナリ。目的 物 一滴, Medium 二投ズルニ八第
11 圖, 如ク 2 枚, 減菌 Deckglas 尹 Moist-Chamber =固定シ其 Proximal , Deckglas，下而，㳇緣二近ク目的物 尹含么液人一滴子置キ Distal , Deckglas，下面中央 $=$ Medium，一滴斗 置キ前記 2 本， Micro-Pipettes 中/ 1 林子以テ可檢物，少量尹吸七取り第 11 墒 a /如》Micro-Praps 7 作ル. 1 個 八菌文八細胞或八头レ等，物，目的數 子含么 Micro-Prup 7 得夕ル時八豫メ Medium 八一滴子吸へル他側, MicroPipette 尹以テ吸七取り b / 如” Distal , Deckglas , Medium , Prup 二近ク 再ビ Micro-Prups 尹作ル.多ク，場合 2 乃至3回ノ操作二テ目们物テ含ム MicroPrup 于認 $\times$ 得. 次二同一Pipette $=$ テ Medium, Prup ，浴緣二觸レ。兩方， Prups /癒合スル瞬間二Pipette 下グ、然ラザレハ目的物ガ再ビ Pipette 內二吸七取ラル、盧レアリ。次二該Deckglas $\Rightarrow$ Moist-Chamber $ヨ$ 離ス. 乾 燥キ防グ䉆メ二 Medium, 一滴 尹底部 二入レタル隇菌 Hohl objektglas 上二 Vaseline 二テ封鎖固定入. 適當ナル液 底部ニ入レル時八嫌氣性條件ョ與フル事 モ可能ナリ。前記條件キ具へタル MicroPipettes 7 用フル時ハ 1 時間 $15-20$ 匹 , 普通大腸菌肺炎雙球菌等分離シ一滴 , Medium 二培養可能ナリ。賽驗上一 定，溫度尹必要卜ス儿場合二八全 Manipulator $尹$ Heizkammer 二入レテ操 作スル事子得。

Micro-Manipulator 二八更 $=$ MicroElectrode 7 應用三得 $(1)$ 水晶, Capillaren 二白金線二入 $レ$ Acetylene 焰上 二テ引延バス法 (1)硼酸, Alcohol 溶液 ト Labender 油卜/混合液子 Platin- 
chloride, Alcohol 溶液二加へタル液二 テ水晶棒き塗リ火熖上ニテ燃ヤス法 (1) 寒天丹監化加里溶液二溶解七ルモ, 用 フル力法等, 記载アリ。 G. Ettisch 及 ビ T. Péterfi 氏八緗胞, Electrometrie
二就キ詳細ナル實驗キ報告セリ。

Micro-Manipulator $尹$ 其他. 物質, 張 力測定. Sole 及ビ Gele, Elasticity，檢 查. 毛細管厴力，测定等二應用七ル實驗 報告モアリ。 終

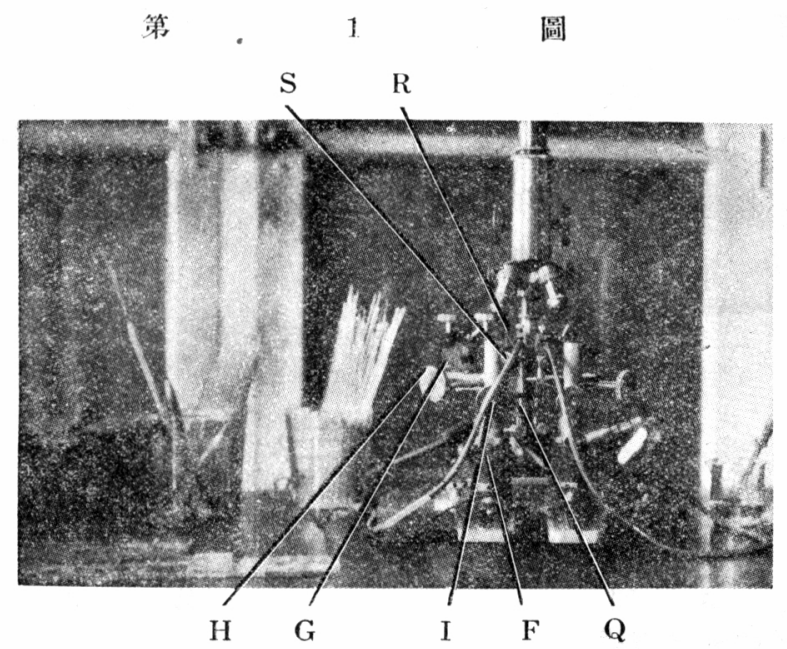

第

2

圖

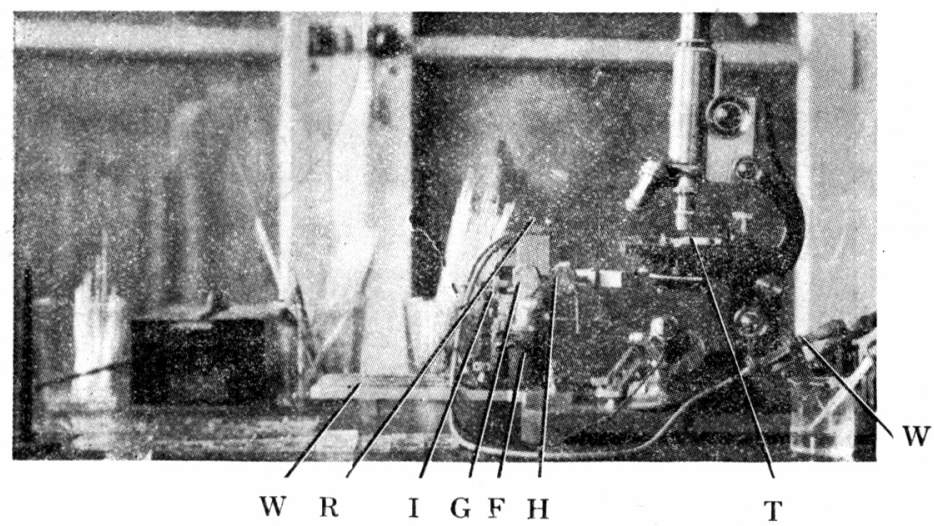


第 3 圖

(Starfisch, ，卵 $=$ Phenol red 注射)

b ....Micro-needlè

a...Micro-pipette，先端量

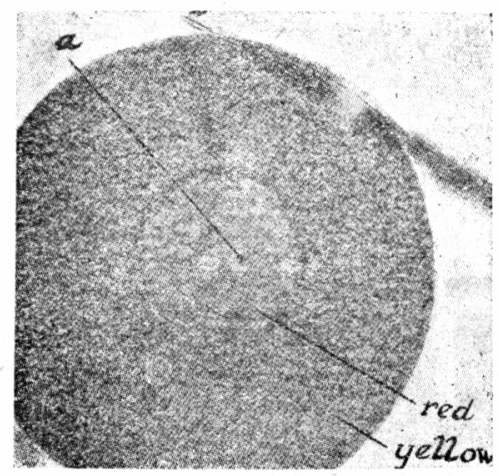

\section{第 4 圖}

(Amphiuma，赤血球）

Dissection, $\times 550$ )

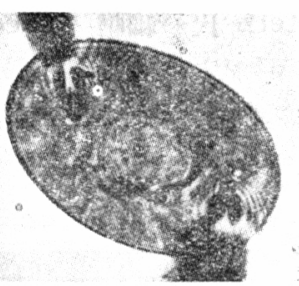

第 5 圖

(Amphiuma, 赤血球

Dissection, $\times 520$ )

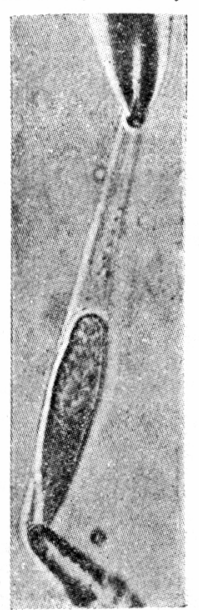

第 6 圖

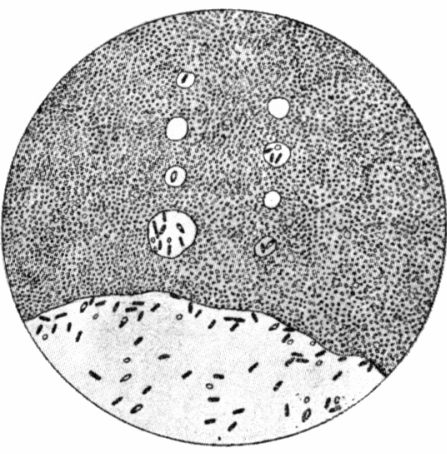



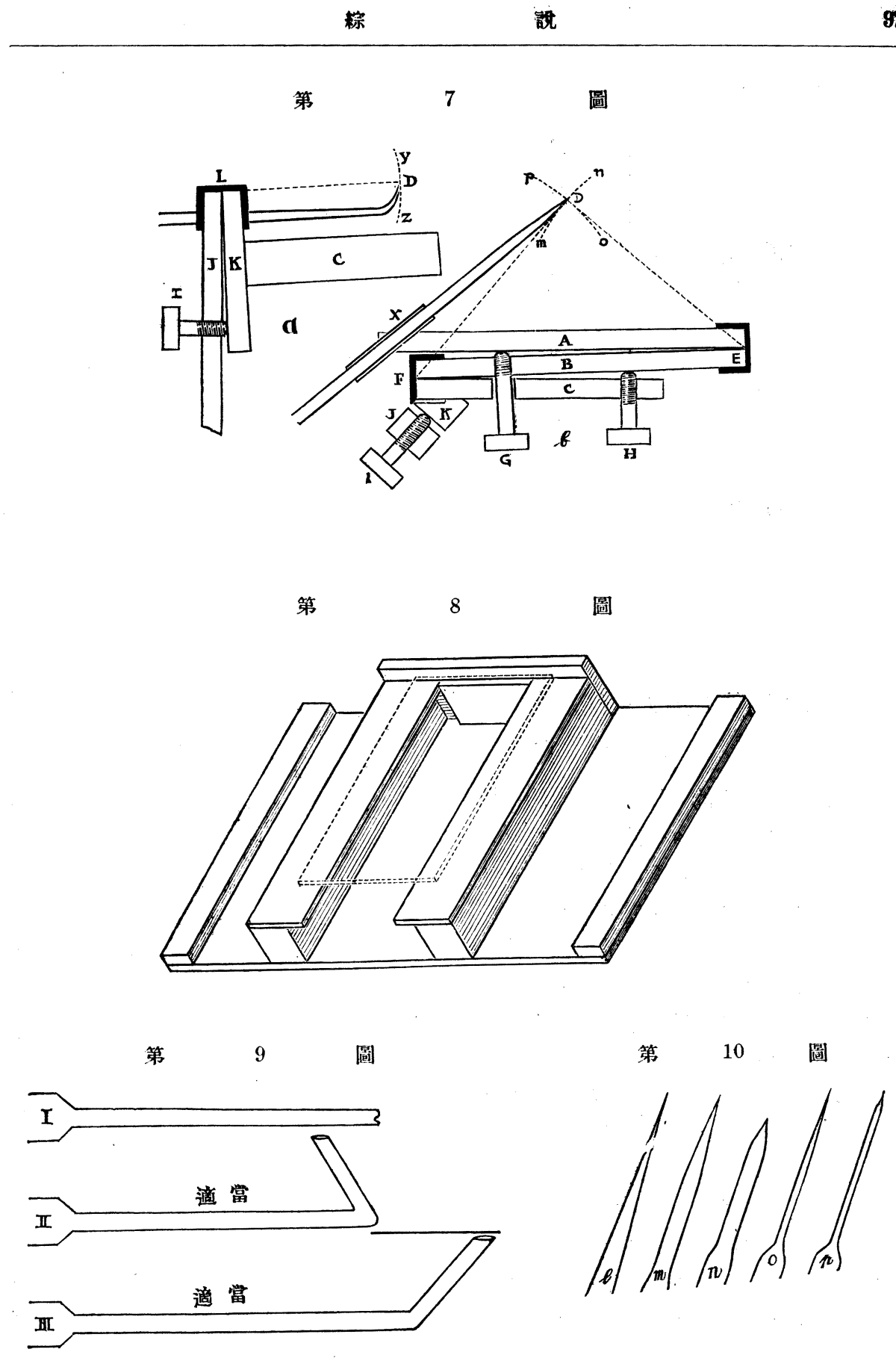
第 11 圖
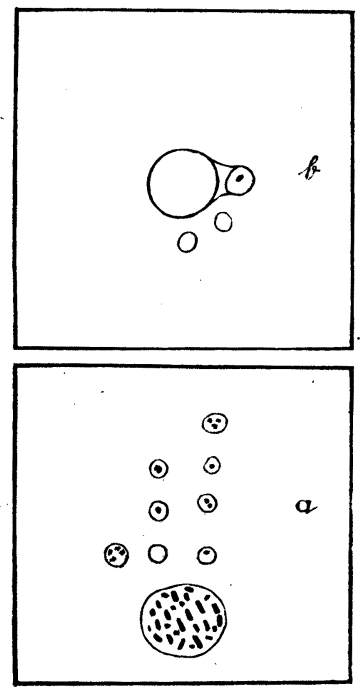

第 12 圖
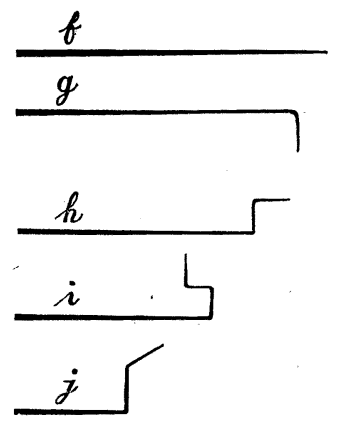

第 13 圖

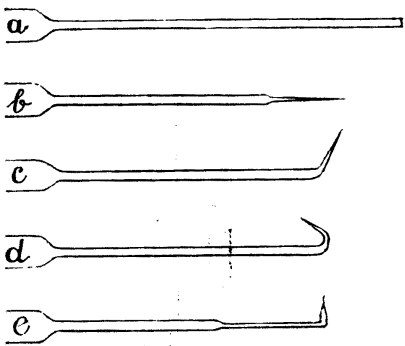

\section{麻菌ノ培養ト癩ノ血清診斷}

田宮真亮

瀬，問題八學術的二見テモ社會的二見 テモ全ク取り殘サレタ狀態ニアリマシテ 文化, 今日ニアツテ八全社會, 協力ニヨ ツテ何卜力解決，曙光き求メ子バナラヌ 次第デアリマス．殊二學術的方面二於テ 八病原體卜認メラレルハンゼン氏癩桿菌 八培養モ充分成功ノ域二達七ズ. 又動物 移植モ迷第客八裡二アリ更二治療二於テハ 天刑不治, 疾病トシテ衆目/怖ル、トコ ロデアリマス．斯ノ如ク制醫學八殊二》 ノ中デモ細菌學的血清學的方面二於イテ 八進展ノ土臺トナルベキ病原菌/皆養卜 動物移植卜ガ出來ナイタメ二全然醫學， 原始狀態二殘サレテキル次第デアッテ泫

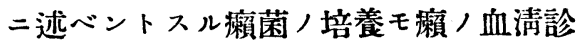
斷モ共ニ「詮ズルトコロ八何物モナイ」ト 言七得ルカモ知レナイガ然シ 1873 年 Armauer Hansen ガ今日所謂嬾桿菌尹
以テ頼, 病原體トシテ提唱シテ以來今日 二至ルマデ 47 年間二八幾多先人, 努力 八相當二認メラレルモノガフリマス．デ 私ハコレカラ制ノ研究き進メテ行クニツ イテ細菌學卜血清學ト二就イテソノ出發 點丹何處二求メルカトイフコトタ考フル トキ二玆ニ二ツノ方法キ見出シタノデア リマス。一ツハ先人ノ跡キ彗于テソノ裡 二自然，琴線二觸レテキルト思ハレルモ ノキ見出スコト．他ノーツハ直接瀨り ノモノ二接シテ獺 デアルガ私ハソ，第 1 /方法二依ツテ先 人ノ跡き尋子テ見度イト思フノデアリマ ス.ソレデ私ハソノ先人ノ跡き器子テ浲 著シタ私ノ興味ト疑閆トチ卒直ニ申シ述 ベテ御敎示チとフトイフコトニ致シマシ タ. 幸二私ノ興味二共鳴願七私ノ疑問 ヨ解イテ下サレバ欣幸二存ズル次第デァ リマス。

僌菌/培養 1888 年 Bordoni u. Uffreduzzi ガ涑菌，培食二成功シタト稱ス 